\title{
IS URBAN TOURISM STILL COMPETITIVE AND SUSTAINABLE? CASE OF BRATISLAVA AND PRAGUE
}

\author{
Alžbeta Királ'ová, Iveta Hamarneh
}

\begin{abstract}
Tourism is attracted to urban areas mostly as a result of the built cultural heritage, urban amenities, lifestyle, cultural traditions, and cultural events. An increasing number of visitors often led to inconvenience for residents and can affect the value of the visited site. Prague and Bratislava are both Capitol cities and are one of the most visited urban destinations in their respective countries. Sustainable development is from this aspect one of the ways how to manage tourism development in the destination. Indicators as Tourist intensity ratio, Tourist density ratio, Tourist penetration ratio, and Defert's tourism function index Defert-Baretje's index, Charvat's index, and Schneider's index were calculated based on the data from 2017to detect the current state of the intensity of visitors flow in the selected destinations. Based on the results obtained in this study, it can be stated that urban tourism in Prague is sustainable if taking into account the whole area of the city. The urban tourism in Bratislava can be further developed sustainably. Both cities are from tourism development still competitive.
\end{abstract}

Keywords: Bratislava, Prague, sustainable development, urban tourism

\section{Introduction}

Tourism has a positive impact on economic growth and employment in destinations; it helps to raise local awareness of the value of natural and cultural sites by supporting local handicrafts, cuisine, traditions or by offering alternative economic activities. Tourism is an essential aspect of the life of people in destinations and a means of achieving community development (Sharpley, Telfer 2002).

On the other side, tourism can disrupt the original lifestyle of the residents and can cause environmental deterioration, traffic congestion, and raise the living costs. Sustainable tourism development can help to avoid the possible negative impact of tourism on the destination. Tourism requests the right balance between economic benefit and undesirable effects. Responsible tourism can be a driver for the preservation of the cultural identity of the urban destinations and a vehicle of their sustainable development. However, if unplanned or not adequately managed, tourism can be social, culturally and economically disruptive, and have a devastating effect on environments and local communities. 
Tourism is to be considered a significantly important part of urban development, as it combines a competitive supply of tourism services, which corresponds to the expectations of tourists, and a positive impact on the development of regions and cities, as well as general prosperity of their citizens (European Commission Tourism Unit, 2008).

Urban areas perform a significant role in social and economic development. They are home to key tourism destinations and attractions, so the issue of sustainable urban development acts significant challenges and opportunities to tourism stakeholders, as well as governments and residents (Ezaki, 2016). It balances the need for development and the need for environment protection (Harris, Griffin, Williams 2002). Schofield (2001) states that urban tourism can create jobs and revenues for a government that is often higher than the income from another type of destinations. The global options for travel destinations are extensive, so cities compete alongside all others, for visits longer than short break or single visits (Dwyer et al., 2009).

Urban tourism is an important and one of the most dynamic forms of tourism; it is one of the leading factors of economic increase in European cities (Delitheou, Vinieratou, and Touri, 2010). The European Cities Marketing (ECM, 2018) reported in its 14th official edition of European Cities Benchmarking Report 2017-2018 that European cities continued their growth with a $6.5 \%$ increase in 2017 in total overnights compared to 2016. Domestic overnights (4.8\%) grew more than international ones $(7.5 \%)$. The average number of beds was 23006 per city.

Tourism competitiveness for an urban destination is about its ability to optimize its attractiveness for residents and visitors, to deliver quality, innovative and attractive services to visitors as well as to gain market shares on the global marketplaces, while ensuring efficient and sustainable use of available resources supporting tourism (Dupeyras \& MacCallum, 2013).

In many urban destinations visitor numbers have been rising steadily for decades, and currently, there are around two billion tourist arrivals per year. Overtourism reduces the quality of life for residents and creates a negative experience for visitors. The term over tourism is used since 2012, but destinations realized its real impact in 2017 when there were marches in the streets in urban destinations (Barcelona), graffiti saying "Tourists go home" (Budapest). The reaction of local authorities was increasing fees (e. g. Dubrovnik), refusing to issue permits for more tourist-focused businesses in city centers (Brugges), and even closing entire islands to visitors (Thailand). Governments, tourist boards, and destination management organizations have for long focused on quantity of arrivals with no attention to the quality of visits.

Competitiveness is widely accepted as the most critical factor in determining the long-term success of destinations (Kozak, Rimmington, 1999). An attractive destination reflects the visitors' feelings and opinions about the destination's ability to satisfy their needs and deliver individual benefits (Mayo, Jarvis, 1981). 
Competitive advantage is based on differentiation and divergence, but the current information sharing means that destinations must reckon with the fact that the competition is watching them and will plan something similar.

The importance of sustainable tourism development for destination competitiveness emphasizes Crouch and Ritchie (1994, 1995) and Ritchie and Crouch (1993, 2000a,b, 2003). Ritchie and Crouch considered a destination competitive if it can increase tourism expenditure and increasingly to attract visitors by offering them satisfying, memorable experiences. They focus on longterm prosperity of the destination and claim that the most competitive destination is that which most effectively creates well-being for its residents on a sustainable basis and underline the importance of economic, ecologic, social, cultural and political sustainability.

\section{Methodology}

The analysis and data presented in this paper are based on primary and secondary research. For detection of the current state of the intensity of visitors flow in the city destinations, indicators as Tourist Intensity Ratio (TIR), Tourist Density Ratio (TDR), Tourist Penetration Ratio (TPR) and Defert's Tourist Function /DTF) Index, Defert-Baretje's Index, Charvat's Index, and Schneider's Index were calculated (Table 1).

Table 1: Tourism indicators

\begin{tabular}{|l|l|}
\hline \multicolumn{1}{|c|}{ Indicator } & \multicolumn{1}{c|}{ Description } \\
\hline Tourist Intensity Ratio (TIR) & The percentage of tourists to the resident population \\
\hline Tourist Density Ratio (TDR) & Percentage of tourists to land area = tourist arrivals/km² \\
\hline Tourism Penetration Ratio (TPR) & $\begin{array}{l}\text { Number of tourists multiplied by average length of stay } \\
\text { and divided by number of population multiplied by 365 } \\
\text { multiplied by 1,000 }\end{array}$ \\
\hline Tourism Density & $\begin{array}{l}\text { Number of overnight per resident; number of tourists per } \\
\text { resident }\end{array}$ \\
\hline Defert's tourist function index (DTF) & $\begin{array}{l}\text { The number of total beds available in the selected area } \\
\text { divided by number of inhabitants multiplied by 100 }\end{array}$ \\
\hline Defert-Baretje's index & $\begin{array}{l}\text { Number of beds multiplied by 100 divided by the number } \\
\text { of local residents, } \\
\text { Multiplied by 1 divided by the surface of researched area, } \\
\text { represented in km2 } \\
\text { - }\end{array}$ \\
\hline Charvat's index & $\begin{array}{l}\text { The intensity of tourism development; the number of } \\
\text { overnights divided by the number } \\
\text { of local residents multiplied by } 100 .\end{array}$ \\
\hline Schneider's index & $\begin{array}{l}\text { The intensity of tourist saturation; the number of tourists } \\
\text { divided by the number of local residents multiplied by } 100\end{array}$ \\
\hline
\end{tabular}

Source: Authors' processing based on De Alburqueque and McElroy, 1998; Jansen-Verbeke, 1995; McElroy, 2003; Smith, Krannich, 1998 
Determinating the tourism potential (primary and secondary tourism elements), literature review, content analysis of documents and Asset Mapping (Dorfman, 1998; Moore, 2012), were conducted.

For Asset Mapping the 2GIS application, a detailed and current information system Prague with a city map and mapa.sk for Bratislava, was used.

The data were obtained from CzechTourism (2018), National Council of the Slovak Republic (2018), Prague City Tourism (2018a,b), Bratislava - hlavné mesto Slovenskej republiky (2018), Czech Statistical Office (2018), Ministry of Regional Development (2018), Statistical Office of the Slovak Republic (2018) for the period of 2017.

According to the objective of the paper the research question was defined as follows: Can be urban tourism perceived as competitive and sustainable in Prague and Bratislava cities?

\section{Results and discussion}

Annual tourism density in the cities included in the report was determined to be 8.33 overnights per citizen. Without a doubt, urban tourism can generate income and employment in the urban area.

Prague is the seventh place on the list of the ECM while to the first five places belong London, Paris, Berlin, Rome, and Madrid; Bratislava is placed around the 50th place from the year of 2016.

The area of Prague is for the performance of the state administration divided into 22 administrative districts and 57 autonomous municipal districts with elected bodies (Table 2 ).

Table 2: Basic characteristics of Prague and Bratislava Cities

\begin{tabular}{|l|r|r|}
\hline \multicolumn{1}{|c|}{ Indicator } & \multicolumn{1}{c|}{ Prague City } & \multicolumn{1}{c|}{ Bratislava City } \\
\hline Size of the area & $496 \mathrm{~km}^{2}$ & $367,6 \mathrm{~km}^{2}$ \\
\hline Number of inhabitants & 1,273 million & 413,192 \\
\hline Population density & 2,581 & 1,124 \\
\hline Administrative districts & inhabitants. $/ \mathrm{km}^{2}$ & inhabitants. $/ \mathrm{km}^{2}$ \\
\hline
\end{tabular}

Source: Author's processing based on data from Prague City Tourism (PCT), 20118a, Bratislava - hlavné mesto Slovenskej republiky, 2018

In 2017, seven million six hundred fifty thousand arrived in Prague; by 7.4 percent more than a year ago (PCT, 2018). The number of overnights in Prague increased in 2017 of $7.5 \%$ to compare to 2016 and reached 18. 055.838, while the average length of stay 2.4 nights remains unchanged. 
The Quality of Life Index of Numbeo ranked Prague 27th with 159,99 points. Quality of Life Index is an estimation of overall quality of life by taking into account purchasing power index, pollution index, house price to income ratio, cost of living index, safety index, healthcare index, traffic commute time index and climate index (Numbeo, 2018).

Prague's historical center belongs since 1992 to the UNESCO World Heritage Sites. There are 1.330 protected objects in this area (including 28 national cultural monuments), 1.322 protected buildings, a large number of small architectural objects, technical monuments, and historic gardens and parks.

The most visited monument in 2017 was the Prague Castle, followed by Petřín Funicular, the Zoological Garden, the AquaPalace and the Petřín Lookout Tower (CzechTourism, 2018).

Table 3: The most visited monuments in Prague City and in Bratislava City (2017)

\begin{tabular}{|l|r|l|r|}
\hline \multicolumn{2}{|c|}{ Prague City } & \multicolumn{2}{c|}{ Bratislava City } \\
\hline Monuments & $\begin{array}{c}\text { Number of } \\
\text { visitors }\end{array}$ & \multicolumn{1}{|c|}{ Monuments } & $\begin{array}{c}\text { Number of } \\
\text { visitors }\end{array}$ \\
\hline Prague Castle & $2,377,600$ & Castle Děvín & $1,135,000$ \\
\hline Petř́n Funicular & $2,066,000$ & St Martin's Cathedral & 800,000 \\
\hline Zoological garden & $1,445,100$ & Bratislava Castle & 500,000 \\
\hline AquaPalace & 835,900 & $\begin{array}{l}\text { The SNU Bridge with } \\
\text { "UFO" Restaurant }\end{array}$ & 200,000 \\
\hline $\begin{array}{l}\text { Petřín Lookout } \\
\text { Tower }\end{array}$ & 713,600 & Blue Church & 150,000 \\
\hline
\end{tabular}

Source: Author's processing based on data from CzechTourism (2018); The city where you find real life (2018); National Council of the Slovak Republic (2018)

Bratislava is the Capital City of the Slovak Republic and for the performance of the state administration it is divided into 17 administrative districts (Table 2).

The number of visitors in Bratislava reached 1291008 in 2017 (an increase of $5.27 \%$ to 2016), while the number of overnights was 2719733 (4.45\% growth to compare to 2016). The average length of stay was 2.11 .

The Quality of Life Index of Numbeo (Numbeo, 2018) ranked Bratislava 34th with 152.22 points.

The most visited monuments in Bratislava were The Devín Castle, the Bratislava Castle, St. Martin's Cathedral, the SNU Bridge with UFO Restaurant and the Blue Church (Table 3). The selected elements of urban tourism in Prague and Bratislava are presented in Table 4. For the detection of the current state of the intensity of visitors flow in Prague and Bratislava, different tourism indicators were calculated (Table 5). 
Table 4: Selected elements of urban tourism in Prague and in Bratislava (2017)

\begin{tabular}{|l|r|r|}
\hline \multicolumn{1}{|c|}{ Selected elements of urban tourism } & \multicolumn{1}{c|}{ Prague City } & Bratislava City \\
\hline \multicolumn{1}{|c|}{ Primary elements } \\
\hline $\begin{array}{l}\text { Number of galleries, museums and other } \\
\text { monuments }\end{array}$ & 34 & 70 \\
\hline Number of organized exhibitions & 398 & 151 \\
\hline $\begin{array}{l}\text { Number of castles, palaces and other } \\
\text { monuments for the admission }\end{array}$ & 17 & 18 \\
\hline Number of cultural events & 1,130 & 589 \\
\hline $\begin{array}{l}\text { Number of conferences in accommodation } \\
\text { establishments }\end{array}$ & 4,437 & 1,348 \\
\hline \multicolumn{2}{|c|}{ Secondary elements } \\
\hline Number of accommodation facilities & 795 & 151 \\
\hline $\begin{array}{l}\text { Number of beds in accommodation } \\
\text { facilities }\end{array}$ & 91,887 & 18,676 \\
\hline Number of gastronomy facilities & 5,758 & 67 \\
\hline $\begin{array}{l}\text { Number of Travel agencies and tour } \\
\text { operators }\end{array}$ & 65 & 4 \\
\hline Number of Tourism information agencies & 9 & 1 \\
\hline Number of Airports & 2 & 2 \\
\hline Number of Train stations & 3 & 67 \\
\hline
\end{tabular}

Source: Author's processing based on results of Asset Mapping; Prague City Tourism (PCT), 2018b; Bratislava - hlavné mesto Slovenskej republiky, 2018; Czech Statistical Office (CSO, 2018); Ministry of Regional Development (MRD, 2018); Statistical Office of the Slovak Republic (SOSR, 2018)

Table 5: Indicators for Prague and Bratislava Cities (2017)

\begin{tabular}{|l|r|r|}
\hline \multicolumn{1}{|c|}{ Indicator } & \multicolumn{1}{c|}{ Prague City } & \multicolumn{1}{c|}{ Bratislava City } \\
\hline Tourist Intensity Ratio (TIR) & 601 & 312 \\
\hline Tourist Density Ratio (TDR) & $15,429 / \mathrm{km}^{2}$ & $3,512 / \mathrm{km}^{2}$ \\
\hline Tourism Penetration Ratio (TPR) & 39,5 & 18 \\
\hline $\begin{array}{l}\text { Tourism Density (No of } \\
\text { overnights/residents); }\end{array}$ & 14,18 & 6,58 \\
No of tourists /residents & $1: 0,17$ & $1: 0,32$ \\
\hline Defert's tourist function index (DTF) & 7,22 & 4,05 \\
\hline Defert-Baretje's index & 2,79 & 6,38 \\
\hline Charvat's index & $1,418,37$ & 658,22 \\
\hline Schneider's index & 600,94 & 312,45 \\
\hline
\end{tabular}

Source: Authors' processing based on data from Prague City Tourism (2018); Czech Statistical Office (CSO, 2018); Ministry of Regional Development (MRD, 2018); Statistical Office of the Slovak Republic (SOSR, 2018) 


\section{Conclusion}

Tourism is to be considered a significantly important part of urban development, as it combines a competitive supply of tourism services, which corresponds to the expectations of tourists, and a positive impact on the development of regions and cities, as well as general prosperity of their citizens (European Commission Tourism Unit, 2008).

Based on the analysis given, the following results can be stated. The tourism intensity measures total overnight stays (or arrivals) concerning the total permanent resident size and provide an estimate of tourism potential. In the context of the sustainability of tourism, it can also be seen as an indicator of the possible tourism pressure. The ratio shows that Prague City (601) has a higher volume of tourism than Bratislava (312) per 1000 of residents.

The Tourist Density Ratio indicates that Prague welcomes nearly four times more tourists per day per $1 \mathrm{~km}^{2}$ than Bratislava. Prague City's Tourist Penetration Ratio indicates more than two times higher number of tourists per day per 1000 inhabitants than Bratislava in the long term.

The Defert's tourist function index for Prague City (7.22) indicates low tourist intensity and that the tourism function of the City is submerged in other urban function. It must be added that this result will be different if only the Prague City Center area would be measured. The Defert's index value for Bratislava (4.05) indicates no tourist intensity.

The Defert-Baretje's index indicates whether tourism development encourages intensive construction of accommodation facilities, which further might threat and change the architectural appearance and will impact the cultural identity of the local population. The value of the index for Prague is less than 4 and indicates that tourism development does not encourage intensive construction of accommodation facilities in the city. However, it must be stated that the situation would be different if counted the data from the protected area of the city center only. Construction of accommodation facilities in Prague already reached its peak, and currently, this activity is slowed down; data from the Czech Statistical Office confirm this. The number of accommodation facilities dropped from 845 in 2012 to 787 in 2017, which means a decrease of seven percent (CSO, 2018). Prague, according to current tourism statistics, was the only region in the Czech Republic in 2017, where the number of overnight stays in accommodation facilities decreased. Overnight stays dropped by 1.1 percent to 5.38 million. The reason was mainly the decrease in the number of nights spent in Prague by guests from abroad by 2.2 percent because foreigners account for almost 90 percent of all overnight stays in the city. Even though tourists from the Czech Republic stayed longer, the drop failed to balance (Volf, 2018).

Charvat's index and Schneider's index are valuable indicators of tourist turnover intensity and tourist saturation. The high intensity of tourism might have a 
negative impact not only on the local population but also on tourists as it can decrease the quality of their experiences. The intensity of tourism development (the Charvat's index values) is double for Prague as for Bratislava. The number of overnights is a valuable indicator of economic development as incomes achieved in this way remain to the local population, with the possibility of investing in further development.

Schneider's index indicates the tourist turnover intensity of specific destination through the number of tourist arrivals. It reflects the intensity of tourist saturation, which refers to the balance between the tourist and general spatial planning for the needs of the local community. The value of the index in Prague shows a double tourism saturation to compare to Bratislava.

The analysis carried out in this study demonstrates disproportions in the range of the indicators. The low value of the Charvat's and Schneider's indexes for Bratislava together with the higher value of the Defert-Baretje's index shows possibilities for further tourism development.

Based on the results obtained in this study, the research question can be answered that urban tourism in Prague is sustainable if taking into account the whole area of the city. The urban tourism in Bratislava can be further developed sustainably. Both cities are from tourism development still competitive.

The opportunities for future research can be seen in widening the research and calculate the indicators for time series data.

\section{Acknowledgement}

The Scientific Paper was elaborated within the framework of the research project "Evaluation of City Tourism Competitiveness: A Comparative Study of Selected Czech Cities" GA/6/2018.

\section{References}

BRATISLAVA - HLAVNÉ MESTO SLOVENSKEJ REPUBLIKY. 2018. [online]. UzemnePlany.sk [quoted to 20. 09. 2018]. Available at: http://www.uzemneplany.sk/upn/bratislava-hlavne-mesto-slovenskej-republiky.

CROUCH, G. I. - RITCHIE, J. R. B. 1994. Destination Competitiveness: Exploring Foundations for a Long-Term Research Program. In Proceedings of the Administrative Sciences Association of Canada 1994 Annual Conference. Halifax: Nova Scotia, pp. 79-88.

CROUCH, G. I. - RITCHIE, J. R. B. 1995. Destination Competitiveness and the Role of the Tourism Enterprise. In Proceedings of the Fourth Annual World Business Congress. Istanbul: Turkey, pp. 43-48. 
CZECHTOURISM. 2018. Návštěvnost turistických cílù 2017 [online]. [quoted to 20. 09. 2018]. Available on: http://www.czechtourism.cz/getattachment/Promedia/Tiskove-zpravy/Navstevnost-turistickych-cilu-v-CR-lakajihistoric/Czech_Tourism_nej_turisticke_cile.pdf.aspx?ext=.pdf.

CZECH STATISTICAL OFFICE. 2018. Regionální časové rady. [online]. [quoted to 20. 09. 2018]. Available on: https://www.czso.cz/csu/czso/regionalni_ casove_rady.

De AlBUQUERQUE, K. - McELROY, J. L. 1992. Caribbean small- island tourism styles and sustainable strategies. In Environmental Management. vol. 16 , no. 5, pp. 619- 632 .

DELITHEOU, V. - VINIERATOU, M. - TOURI, M. 2010. The contribution of public and private investments to the growth of conference tourism in Greece. In Management Research and Practice. vol. 2, no. 2, pp. 165-178.

DORFMAN, D. 1998. Mapping Community Assets Workbook. Portland: Northwest Regional Educational Laboratory.

DUPEYRAS, A. - MACCALLUM, N. 2013. Indicators for Measuring Competitiveness in Tourism: A Guidance Document. [online]. OECD Tourism Papers, 2013/02, OECD Publishing. [quoted to 01. 06. 2018]. Available at: http://www.oecd.org/cfe/tourism/Indicators\%20for\%20Measuring\%20Competi tiveness\%20in\%20Tourism.pdf.

DWYER, L. - EDWARDS, D. - MISTILIS, N. - ROMAN, C. - Scott, N. 2009. Destination and enterprise management for a tourism future. In Tourism Management. vol. 30, pp. 63-74.

ECM 2018. The European Cities Marketing Benchmarking Report. $14^{\text {th }}$ Official Eddition 2017-2018. Dijon: European Cities Marketing.

EUROPEAN COMMISSION TOURISM UNIT 2008. Prieiga per interneta. [online]. [quoted to 01. 06. 2018]. Available at: http://ec.europa.eu/enterprise/ services/tourism/index_en.htm.

EZAKI, A. 2016. World Cities Day: Sustainable Urban Tourism Issues and Solutions. [online]. [quoted to 01. 06. 2018]. Available at: https://www.trainingaid.org/news/world-cities-day-sustainable-urban-tourismissues-and-solutions.

HARRIS, R. - WILLIAMS, P. - GRIFFIN, T. (eds). 2002. Sustainable Tourism. Second Edition: A Global Perspective. New York: Routledge.

HASAN, S. 2015. Carrying Capacity Assessment for Sustainable Tourism Development: A Proposal for the Saint Martin's Island. [online]. [quoted to 01. 06. 2018]. Available at: http://www.academia.edu/5367565/Carrying _ Capacity_Assessment_for_Sustainable_Tourism_Development_A_Proposal_fo r_the_Saint_Martins_Island.

JANSEN-VERBEKE, M. - SPEE, R. 1995. A regional analysis of tourist flows within Europe. In Tourism Management. vol. 16, no. 1, pp. 73-80.

KOZAK, M. - RIMMINGTON, M. 1999. Measuring Tourist Destination 
Competitiveness: Conceptual Considerations and Empirical Findings. In Hospitality Management. vol. 18, no. 3, 273-283.

MATHIESON, A. - WALL, G. 1982. Tourism: Economic, Physical and Social Impacts, New York: Longman.

MAYO, E. - JARVIS, L. 1981. The Psychology of Leisure Travel. Boston: CBI Publishing.

McCOOL, S. F. 1994. Planning for sustainable nature dependent tourism development: the Limits of Acceptable Change system. In Tourism Recreation Research. vol. 19, no. 2, pp. 51-55.

McELROY, J. 2003. Tourism Development in Small Islands across the World. In Geografiska Annaler. vol. 85, no. 4, pp. 231-242.

Ministry of Regional Development, 2018. Statistiky a analyzzy. [online]. [quoted to 01. 06. 2018]. Available on: http://www.mmr.cz/cs/Regionalni-politika-acestovni-ruch/Cestovni-ruch/Statistiky-Analyzy.

MOORE, S. 2012. Cultural Mapping: Building and Fostering Strong Communities. In Borwick, D. (ed.) Building Communities, Not Audiences: The Future of the Arts in the United States. Winston-Salem: ArtsEngaged.

MOWFORTH, M. - MUNT, I. 2003. Tourism and Sustainability. Development and New Tourism in the Third World. 2nd ed. New York: Routledge.

NATIONAL COUNCIL OF THE SLOVAK REPUBLIC 2018. [online]. [quoted to 01. 06. 2018]. Available at: https://www.nrsr.sk/web/.

NUMBEO. 2018. Quality of Life Comparison Between Prague and Bratislava Belgrade-Zvezdara: Numbeo. [online]. [quoted to 01. 06. 2018]. Available at: https://www.numbeo.com/quality-of-life/compare_cities.jsp?country1=Czech +Republic\&country2=Slovakia\&city $1=$ Prague $\&$ city $2=$ Bratislava\&tracking=get DispatchComparison.

PRAGUE CITY TOURISM. PCT. 2018a. Statistiky a analýzy. [online]. [quoted to 01. 06. 2018]. Available at: https://www.praguecitytourism.cz/cs/nasecinnost/statistiky.

PRAGUE CITY TOURISM. PCT. 2018b. V roce 2017 prijielo do Prahy přes 7,5 milionu návštěvníků. [online]. [quoted to 01. 06. 2018]. Available at: https://www.praguecitytourism.cz/cs/media/tisk/v-roce-2017-prijelo-do-prahypres-75-milionu-navstevniku-14636.

RITCHIE, J. R. - CROUCH, G. I. 1993. Competitiveness in International Tourism: A Framework for Understanding and Analysis. Proceedings of the 43rd Congress of Association Internationale d'Experts Scientifique de Tourisme on Competitiveness of Long-Haul Tourist Destinations, pp. 23-71. San Carlos de Bariloche, Argentina.

RITCHIE, J. B. R. - CROUCH, G. I. 2000a. The Competitive Destination: A Sustainability Perspective. In Tourism Management. vol. 21, no. 1, pp. 1-7.

RITCHIE, J. R. B. - CROUCH, G. I. 2000b. Are Destination Stars Born or Made: Must a Competitive Destination Have Star Genes? In Proceedings of the 31st 
Annual Travel and Tourism Research Association Conference, pp. 306-315. California: Burbank.

RITCHIE, J. R. B. - CROUCH, G. I. 2003. The Competitive Destination: A Sustainable Tourism Perspective. Wallingford, UK: CABI Publishing.

SAARINEN, J. 2006. Traditions of Sustainability in Tourism Studies. In Annals of Tourism Research. vol. 33, no. 4, pp. 1121-1140.

SHARPLEY, R. - TELFER, D. J. 2002. Tourism and Development: Concepts and Issues. Channel View Publications: Clevedon.

SCHOFIELD, P. 2001. Urban tourism and small business. In: Douglas, N., Douglas, N., Derrett, R. (eds) Special Interest Tourism: Context and Cases. pp. 432-450. John Wiley, Brisbane.

SINGH, S. 2006. What's Wrong With Carrying Capacity For Tourism? In Tourism Recreation Research. vol. 31, no. 2, pp. 67-72.

SMITH, M. D. - KRANNICH, R. S. 1998. Tourism Dependence and Resident Attitudes. In Annals of Tourism Research. vol. 25, no. 4, pp.783-802.

STATISTICAL OFFICE OF THE SLOVAK REPUBLIC. 2018. [online]. Tourism [quoted to 20. 09. 2018]. Available at: https://slovak.statistics.sk/

THE CITY WHERE YOU FIND REAL LIFE 2018. [online]. [quoted to 01. 06. 2018]. Available at: https://www.visitbratislava.com/

UNWTO 1981. Saturation of Tourist Destinations: Report of the Secretary General, Madrid: World Tourism Organization.

VOLF, T. 2018. V soukromí bydlí víc než třetina návštěvníků Prahy, některé hotely končí. [online]. [quoted to 12. 11. 2018]. Available at: https://www.novinky.cz/ekonomika/488674-v-soukromi-bydli-vic-nez-tretinanavstevniku-prahy-nektere-hotely-konci.html.

\section{Doc. Ing. Alžbeta Királ'ová, Ph.D.}

University College of Business in Prague Spálená 76/14, Prague 1, Czech Republic E-mail: kiralova@vso-praha.eu

Ing. Iveta Hamarneh, Ph.D. University College of Business in Prague Spálená 76/14, Prague 1, Czech Republic E-mail: hamarneh@vso-praha.eu 